\title{
Early experience with topical meloxicam and lidocaine combination for the treatment of vulvodynia
}

Rufina Kim, BSc ${ }^{1}$; Kerri-Lynn Kelly, $\mathrm{RN}^{1}$; Merle Olsen, $\mathrm{PhD}^{2,3}$; J. Curtis Nickel, MD, FRCSC $^{1}$

${ }^{1}$ Department of Urology, Queen's University, Kingston, ON; ${ }^{2}$ Department of Biomedical Engineering, Faculty of Medicine and Dentistry, University of Alberta, Edmonton, AB; ${ }^{3}$ VP Research, Chief Medical, Calgary, AB; Canada

Cite as: Can Urol Assoc J 2018 April 6; Epub ahead of print.

http://dx.doi.org/10.5489/cuaj.4976

Published online April 6, 2018

$* * *$

\section{Abstract}

Introduction: We report our early clinical observations on the use of topical meloxicam and lidocaine gel for patients with vulvodynia.

Methods: This is an early experience in participants with a history of vulvodynia evaluated and treated at the Queen's University Pelvic and Bladder Pain Clinic.

Combination meloxicam $0.3 \%$ and lidocaine $5 \%$ were provided to the participants and they were instructed to apply 5 cc to the vulvar area twice daily. Standardized assessment was conducted for each participant before the start of the topical therapy and again at one week included Interstitial Cystitis Symptom Index (ICSI), Interstitial Cystitis Problem Index (ICPI), and pain scoring (Likert) for vulvar pain, in addition to a subjective global assessment after a week of treatment.

Results: Of the eight participants, six had a subjective improvement in their symptoms with the use of the combination gel. They reported between one- and four-point reductions on the Likert pain scale and mild to moderate improvement of symptoms. Common side effects reported were burning and stinging.

Conclusions: The results from this early experience are promising for a potentially effective topical treatment for vulvodynia. 


\section{Introduction}

Vulvodynia, defined as a chronic idiopathic vulvar pain, remains a condition of mystery for urologists. Currently, no standardized subtypes of vulvodynia exist, but it is often described as local or generalized and primary (onset prior to sexual activity) or secondary (acquired) ${ }^{1}$ with provoked vulvodynia (PVD) being distinguished from spontaneous vulvodynia. ${ }^{2}$

Few modalities of treatment have been empirically validated. Treatments with some proven efficacy are individual or group cognitive behavioural therapy (CBT), ${ }^{3,4}$ pelvic floor physical therapy, ${ }^{5-7}$ and vestibulectomy. ${ }^{8,9}$ Medical management of vulvodynia presents a conspicuous gap in empirically validated recommendations. ${ }^{10}$ Various medical therapies, including topical (e.g., lidocaine gel or cream, comolyn cream) and systemic agents (e.g., amitriptyline, calcium citrate, desipramine, gabapentin, paroxetine, venlaxafine), have been studied in small trials and case reports. ${ }^{11}$ However, large-scale controlled trials have yet to identify an effective and safe drug management strategy for vulvodynia.

Topical agents have been gaining favour for chronic pain syndromes due to their higher local bioavailability and fewer systemic side effects, leading to greater patient adherence. ${ }^{12}$ Numerous case series and small RCTs suggest clinical value of various local agents for vulvodynia, including topical capsaicin, ${ }^{13,14}$ Botox injections, ${ }^{15-17}$ interferon injections, ${ }^{18-20}$ topical estrogen, ${ }^{21}$ and local anesthetics (e.g., lidocaine).

Peripheral sensitization of nociceptors has been demonstrated as a possible mechanism of vulvodynia. ${ }^{23}$ Such is the rationale for the use of local anesthetics, such as lidocaine, which work by blocking sodium channels in neurons, thereby increasing the threshold for depolarization. ${ }^{24}$ The lidocaine $5 \%$ patch has been used to effectively treat various neuropathic pain conditions. ${ }^{25-27}$ A prospective RCT found that lidocaine and CBT significantly improved vestibular pain thresholds, quality of life scores, and sexual functioning at 12-month follow-up. ${ }^{22}$

Inflammation is one of the key processes involved in vulvodynia. ${ }^{28}$ Case series using combination lidocaine plus methylprednisolone ${ }^{29}$ or betamethasone ${ }^{30,31}$ showed promising results. However, because of a lack of high power studies for the efficacy of topical steroids and a significant side effect profile, the use of steroids is currently not recommended to treat vulvodynia. ${ }^{10}$

NSAID-mediated analgesia is achieved by inhibition of COX-2 enzymes, thereby inhibiting prostaglandin production. ${ }^{32}$ Meloxicam is a selective COX-2 inhibitor with low molecular mass and high tissue tolerability, ${ }^{33}$ and as a result meloxicam has a high intrinsic activity combined with a low ulcerogenic potential it has a therapeutic index lower than piroxicam, diclofenac and indomethacin. ${ }^{34-36}$ 
Bacchav and Patravale ${ }^{37}$ created a topical formulation of meloxicam demonstrating physicochemical stability, excellent in vivo skin penetration, and a lack of skin irritation using the Draize test. The mechanism of the topical delivery of NSAIDs is still unclear but it is believed that local accumulation of the drug in target tissues could occur either by direct penetration or via redistribution through systemic circulation. ${ }^{38,39}$ It has been shown that local, targeted. subcutaneous NSAID delivery might be possible and effective through topical delivery. ${ }^{39}$

We postulate that the topically applied combination meloxicam and lidocaine would synergistically reduce nociceptive thresholds in patients diagnosed with vulvodynia, resulting in symptom amelioration.

\section{Methods}

\section{Patients}

The Queen's University Pelvic/Bladder Pain Clinic evaluates patients presenting with interstitial cystitis, bladder pain syndrome and other urological pelvic pain problems using a standardized protocol. ${ }^{40}$ Approximately $17 \%$ of patients assessed also complain of or are diagnosed with vulvodynia. Our standard clinic approach has been to prescribe lidocaine cream locally and amitriptyline systematically, but this has led to unsatisfactory results in many patients. Based on rationale outlined in the Introduction section, we offered vulvodynia patients who have failed our standard treatment protocol a compounded combination lidocaine/meloxicam topical gel.

\section{Intervention}

Combination lidocaine 5\% and meloxicam 0.3\% was formulated (Chief Pharmacy, Calgary, Alberta, Canada) and provided to patients in 50 cc labeled jars. Patients were instructed to use 5 cc applied to vulvar area BID.

Assessments

All patients underwent standardized evaluation which included focused history and physical examination (including pelvic examination with Q-tip test for vulvodynia), Interstitial Cystitis Symptom Index (ICSI) and Interstitial Cystitis Problem Index (ICPI), Pain scoring (Likert) for various pain generators including vulvar pain was noted. Patients were assessed one week later with ICSI and ICPI, pain evaluation and subjective global assessment (SGA). SGA was a 6 point questionnaire in which the patients described their symptoms as Markedly worse, Moderately worse, Mildly worse, No change, Mildly better, Moderately better and Markedly better. Responders were defined as patients who indicated that their general symptoms were moderately or markedly better following the intervention. 
Analysis

The response in terms of pain score and SGA in this early experience observational study were analyzed descriptively. Since this was not a clinical trial, no effort was made to power this analysis of pilot data based on first experience with this local combination intervention.

\section{Results}

Eight of the ten patients offered the topical therapy applied it at least once. Seven of the eight treated patients had failed our standard vulvodynia intervention and the remaining patient had no previous treatment for vulvodynia. Of the eight participants, six had a subjective improvement in their symptoms with the use of the combination gel (Table 1). A pain score reduction between 1 and 4 were reported one week after starting the use of the topical agent. The other two participants saw a worsening of their symptoms, but they reported no change in their pain scores (see Table 1). The most common side effects reported were burning and stinging.

\section{Discussion}

Most of the participants had tried recommended therapies for vulvodynia and experienced no improvement. The majority reported moderate improvement of their symptoms after a one-week trial of topical lidocaine $5 \%$ and meloxicam $0.3 \%$ combination agent. No systemic side effects were reported, corroborating the current evidence that topical agents have fewer systemic side effects. ${ }^{12}$ Two participants discontinued use due to local adverse effects such as burning and itching. These local side effects were likely attributable to the lidocaine ${ }^{41,42}$ rather than the meloxicam. ${ }^{41}$

In theory, the mechanism by which meloxicam exerts its analgesic effect is via selective COX-2 inhibition as demonstrated in studies of systemic administration. ${ }^{43}$ Meloxicam may have an additional or alternate mechanism of action when applied topically, such as inhibition of NMDA receptor hyperalgesia as observed with topical

application of diclofenac. ${ }^{44,45}$ If true, the combination of meloxicam and lidocaine may work synergistically on the nociceptive threshold to produce an analgesic effect.

\section{Conclusion}

The results from this early experience are promising for a potentially effective topical treatment for vulvodynia. A properly designed randomized placebo-controlled trial is the next step to demonstrate efficacy and characterize any adverse effects. 


\section{References}

1. Pukall CF. Primary and secondary provoked vestibulodynia: A review of overlapping and distinct factors. Sex Med Rev 2016;4:36-44.

2. Edwards L. Vulvodynia. Clin Obstet Gynecol 2015;58:143-52.

3. Bergeron S, Khalifé S, Glazer HI, et al. Surgical and behavioral treatments for vestibulodynia: two-and-one-half year follow-up and predictors of outcome. Obstet Gynecol 2008;111:159-66.

4. Bergeron S, Khalifé S, Dupuis M-J, et al. A randomized clinical trial comparing group cognitive-behavioral therapy and a topical steroid for women with dyspareunia. J Consult Clin Psychol 2016;84:259-68.

5. Dionisi B, Anglana F, Inghirami P, et al. Use of transcutaneous electrical stimulation and biofeedback for the treatment of vulvodynia (vulvar vestibular syndrome): result of 3 years of experience. Minerva Ginecol 2008;60:485-91.

6. Glazer HI, Rodke G, Swencionis C, et al. Treatment of vulvar vestibulitis syndrome with electromyographic biofeedback of pelvic floor musculature. $J$ Reprod Med 1995;40:283-90.

7. McKay E, Kaufman RH, Doctor U, et al. Treating vulvar vestibulitis with electromyographic biofeedback of pelvic floor musculature. J Reprod Med 2001;46:337-42.

8. Tommola P, Unkila-Kallio L, Paavonen J. Surgical treatment of vulvar vestibulitis: a review. Acta Obstet Gynecol Scand 2010;89:1385-95.

9. Woodruff JD, Genadry R, Poliakoff S. Treatment of dyspareunia and vaginal outlet distortions by perineoplasty. Obstet Gynecol 1981;57:750-4.

10. Goldstein AT, Pukall CF, Brown C, et al. Vulvodynia: Assessment and treatment. $J$ Sex Med 2016;13:572-90.

11. Reed BD. Vulvodynia: diagnosis and management. Am Fam Physician 2006;73:1231-8.

12. Jorge LL, Feres CC, Teles VE. Topical preparations for pain relief: efficacy and patient adherence. $J$ Pain Res 2010;4:11-24.

13. Murina F, Radici G, Bianco V. Capsaicin and the treatment of vulvar vestibulitis syndrome: a valuable alternative? MedGenMed 2004;6:48.

14. Steinberg AC, Oyama IA, Rejba AE, et al. Capsaicin for the treatment of vulvar vestibulitis. Am J Obstet Gynecol 2005;192:1549-53.

15. Brown CS, Glazer HI, Vogt V, et al. Subjective and objective outcomes of botulinum toxin type A treatment in vestibulodynia: pilot data. J Reprod Med 2006;51:635-41. 
16. Dykstra DD, Presthus J. Botulinum toxin type A for the treatment of provoked vestibulodynia: an open-label, pilot study. J Reprod Med 2006;51:467-70.

17. Romito S, Bottanelli M, Pellegrini M, et al. Botulinum toxin for the treatment of genital pain syndromes. Gynecol Obstet Invest 2004;58:164-7.

18. Bornstein J, Pascal B, Abramovici $H$. Treatment of a patient with vulvar vestibulitis by intramuscular interferon beta; a case report. Eur J Obstet Gynecol Reprod Biol 1991;42:237-9.

19. Kent HL, Wisniewski PM. Interferon for vulvar vestibulitis. J Reprod Med 1990;35:1138-40.

20. Marinoff SC, Turner ML, Hirsch RP, et al. Intralesional alpha interferon. Costeffective therapy for vulvar vestibulitis syndrome. J Reprod Med 1993;38:19-24.

21. Foster DC, Palmer M, Marks J. Effect of vulvovaginal estrogen on sensorimotor response of the lower genital tract: a randomized controlled trial. Obstet Gynecol 1999;94:232-7.

22. Danielsson I, Torstensson T, Brodda-Jansen G, et al. EMG biofeedback versus topical lidocaine gel: a randomized study for the treatment of women with vulvar vestibulitis. Acta Obstet Gynecol Scand 2006;85:1360-7.

23. Bohm-Starke N, Hilliges M, Brodda-Jansen G, et al. Psychophysical evidence of nociceptor sensitization in vulvar vestibulitis syndrome. Pain 2001;94:177-83.

24. Lidoderm Product Information. Endo Pharmaceuticals 2013. Available from: www.lidoderm.com.

25. Likar R, Demschar S, Kager I, et al. Treatment of localized neuropathic pain of different etiologies with the $5 \%$ lidocaine medicated plaster - a case series. Int J Gen Med 2015;8:9-14.

26. Barbano RL, Herrmann DN, Hart-Gouleau S, et al. Effectiveness, tolerability, and impact on quality of life of the $5 \%$ lidocaine patch in diabetic polyneuropathy. Arch Neurol 2004;61:914-8.

27. Meier $T$, Wasner $G$, Faust M, et al. Efficacy of lidocaine patch $5 \%$ in the treatment of focal peripheral neuropathic pain syndromes: a randomized, double-blind, placebo-controlled study. Pain 2003;106:151-8.

28. Keppel Hesselink JM, Kopsky DJ, Sajben NL. Vulvodynia and proctodynia treated with topical baclofen $5 \%$ and palmitoylethanolamide. Arch Gynecol Obstet 2014;290:389-93.

29. Murina F, Tassan $P$, Roberti $P$, et al. Treatment of vulvar vestibulitis with submucous infiltrations of methylprednisolone and lidocaine. An alternative approach. J Reprod Med 2001;46:713-6. 
30. Dede M, Yenen MC, Yilmaz A, et al. Successful treatment of persistent vulvodynia with submucous infiltration of betamethasone and lidocaine. Eur J Obstet Gynecol Reprod Biol 2006;124:258-9.

31. Segal D, Tifheret H, Lazer S. Submucous infiltration of betamethasone and lidocaine in the treatment of vulvar vestibulitis. Eur J Obstet Gynecol Reprod Biol 2003;107:105-6.

32. Cashman JN. The mechanisms of action of NSAIDs in analgesia. Drugs 1996;52:S13-23.

33. Stei P, Kruss B, Wiegleb J, et al. Local tissue tolerability of meloxicam, a new NSAID: indications for parenteral, dermal and mucosal administration. $\mathrm{Br} \mathrm{J}$ Rheumatol 1996;35:S44-50.

34. Churchill L, Graham AG, Shih C-K, et al. Selective inhibition of human cyclooxygenase-2 by meloxicam. Inflammopharmacology 1996;4:125-35.

35. Engelhardt G, Bögel R, Schnitzler C, et al. Meloxicam: influence on arachidonic acid metabolism. Part II. In vivo findings. Biochem Pharmacol 1996;51:29-38.

36. Pairet M, van Ryn J, Schierok H, et al. Differential inhibition of cyclooxygenases-1 and -2 by meloxicam and its 4'-isomer. Inflamm Res Off J Eur Histamine Res Soc Al 1998;47:270-6.

37. Bachhav YG, Patravale VB. Formulation of meloxicam gel for topical application: In vitro and in vivo evaluation. Acta Pharm Zagreb Croat 2010;60:153-63.

38. Heyneman CA, Lawless-Liday C, Wall GC. Oral versus topical NSAIDs in rheumatic diseases: a comparison. Drugs 2000;60:555-74.

39. Li YJ, Pan Y, Wei G, et al. Pharmacokinetics and local tissue disposition of piroxicam following topical and oral application in rats. J Chin Pharm Sci 2002;11:85-90.

40. Nickel JC, Tripp DA, Pontari M, et al. Interstitial cystitis/painful bladder syndrome and associated medical conditions with an emphasis on irritable bowel syndrome, fibromyalgia and chronic fatigue syndrome. J Urol 2010;184:1358-63.

41. Binder A, Bruxelle J, Rogers P, et al. Topical 5\% lidocaine (lignocaine) medicated plaster treatment for post-herpetic neuralgia: results of a double-blind, placebocontrolled, multinational efficacy and safety trial. Clin Drug Investig 2009;29:393408.

42. Comer AM, Lamb HM. Lidocaine patch 5\%. Drugs 2000;59:245-9.

43. Asghar W, Jamali F. The effect of COX-2-selective meloxicam on the myocardial, vascular and renal risks: a systematic review. Inflammopharmacology 2015;23:116.

44. Dong X-D, Svensson P, Cairns BE. The analgesic action of topical diclofenac may be mediated through peripheral NMDA receptor antagonism. Pain 2009;147:36-45. 
45. Gan TJ. Diclofenac: an update on its mechanism of action and safety profile. Curr Med Res Opin 2010;26:1715-31. 


\section{Figures and Tables}

\section{Table 1. Early experience data}

\begin{tabular}{|c|c|c|c|c|c|c|c|c|c|}
\hline ID & Age & $\begin{array}{l}\text { Symptom } \\
\text { duration } \\
\text { (yrs) }\end{array}$ & Associated conditions & $\begin{array}{c}\text { Previous } \\
\text { treatment(s) for } \\
\text { vulvodynia }\end{array}$ & $\begin{array}{l}\text { ICSI/ICPI } \\
\text { pre vs. post }\end{array}$ & $\begin{array}{l}\text { Pain } \\
\text { score } \\
\text { prior }\end{array}$ & $\begin{array}{l}\text { Pain } \\
\text { score } 1 \\
\text { week } \\
\text { post }\end{array}$ & $\begin{array}{l}\text { Subjective } \\
\text { global } \\
\text { assessment }\end{array}$ & $\begin{array}{c}\text { Reported } \\
\text { side effects }\end{array}$ \\
\hline 1 & 23 & 4 & IBS, anxiety, urethral pain & $\begin{array}{l}\text { Lidocaine cream, } \\
\text { amitriptyline }\end{array}$ & $\begin{array}{l}\text { Pre: } 14 / 13 ; \\
\text { Post: } 14 / 13\end{array}$ & 6 & 5 & $\begin{array}{c}\text { Mildly } \\
\text { improved }\end{array}$ & Stinging $^{*}$ \\
\hline 2 & 20 & 1 & $\begin{array}{c}\text { Anxiety, depression, } \\
\text { endometriosis, persistent } \\
\text { pelvic pain }\end{array}$ & $\begin{array}{l}\text { Physiotherapy, } \\
\text { lidocaine cream }\end{array}$ & $\begin{array}{l}\text { Pre: } 3 / 4 ; \\
\text { Post: } 3 / 4\end{array}$ & 10 & 10 & $\begin{array}{l}\text { Moderately } \\
\text { worse }\end{array}$ & $\begin{array}{c}\text { Stinging, } \\
\text { burning }\end{array}$ \\
\hline 3 & 43 & 8 & $\begin{array}{c}\text { IBS, urethral pain, } \\
\text { endometriosis, } \\
\text { dyspareunia, chronic yeast } \\
\text { infection }\end{array}$ & $\begin{array}{l}\text { Amitriptyline, anti- } \\
\text { histamine }\end{array}$ & $\begin{array}{l}\text { Pre: } 15 / 16 ; \\
\text { Post 19/16 }\end{array}$ & 8 & 4 & $\begin{array}{c}\text { Moderately } \\
\text { improved }\end{array}$ & $\begin{array}{l}\text { Stinging }{ }^{*} \text {, } \\
\text { burning }\end{array}$ \\
\hline 4 & 72 & 19 & $\begin{array}{c}\text { Dyspareunia, IBS, } \\
\text { depression, fibromyalgia, } \\
\text { vaginal atrophy }\end{array}$ & $\begin{array}{c}\text { Tramacet, } \\
\text { physiotherapy, } \\
\text { lyrica, premarin }\end{array}$ & $\begin{array}{l}\text { Pre: } 11 / 4 ; \\
\text { Post: NC }\end{array}$ & 9 & 6 & $\begin{array}{c}\text { Moderately } \\
\text { improved }\end{array}$ & Itching ${ }^{*}$ \\
\hline 5 & 69 & 2 & $\begin{array}{c}\text { IBS, dyspareunia, urethral } \\
\text { pain }\end{array}$ & Amitriptyline & $\begin{array}{l}\text { Pre: NC; } \\
\text { Post: NC }\end{array}$ & 7 & 4 & $\begin{array}{c}\text { Moderately } \\
\text { improved }\end{array}$ & Numbness $^{*}$ \\
\hline 6 & 45 & 2 & $\begin{array}{l}\text { Dyspareunia, chonic } \\
\text { constipation, anxiety }\end{array}$ & None & $\begin{array}{l}\text { Pre: } 17 / 13 ; \\
\text { Post: NC }\end{array}$ & 8 & 8 & $\begin{array}{l}\text { Moderately } \\
\text { worse }\end{array}$ & $\begin{array}{c}\text { Stinging, } \\
\text { burning, labia }\end{array}$ \\
\hline
\end{tabular}


Topical meloxicam/lidocaine combo for vulvodynia

\begin{tabular}{|l|c|c|c|c|c|c|c|c|}
\hline & & & & & & swelling \\
\hline 7 & 54 & 10 & $\begin{array}{c}\text { Vaginal atrophy, urethral } \\
\text { pain }\end{array}$ & $\begin{array}{c}\text { Lidocaine cream, } \\
\text { premarin, } \\
\text { amitriptyline }\end{array}$ & $\begin{array}{c}\text { Pre: } 14 / 13 ; \\
\text { Post: NC }\end{array}$ & 8 & 6 & $\begin{array}{c}\text { Mildly } \\
\text { improved }\end{array}$ \\
\hline 8 & 35 & 1 & Traumatic birth & $\begin{array}{c}\text { Physiotherapy, } \\
\text { lidocaine cream, } \\
\text { PF }\end{array}$ & $\begin{array}{c}\text { Pre: } 14 / 11 ; \\
\text { Post: } 11 / 10\end{array}$ & 8 & 6 & $\begin{array}{c}\text { Mildly } \\
\text { improved }\end{array}$ \\
\hline
\end{tabular}

Side effects only experienced during first few applications and resolved by one week assessment. NC: not completed. 
